\title{
ON THE WATER CHANNELS OF THE INTERNAL DRAINAGE SYSTEM OF THE HINTEREISFERNER, ÖTZTAL ALPS, AUSTRIA
}

\author{
By H. Behrens, H. Bergmann, H. Moser, \\ (Institut für Radiohydrometrie der Gesellschaft für Strahlen und Umweltforschung mbH, \\ München, Germany) \\ W. Амвасн and O. Jochum \\ (Physikalisches Institut der Universität Innsbruck, Innsbruck, Austria)
}

\begin{abstract}
Studies that had been started in 1971 were continued in the summer of 1972 in order to gather information on the intraglacial run-off system in the ablation region of Hintereisferner. In a long-term test of $30 \mathrm{~h}$, the daily fluctuations of the inflow into a moulin and the discharge at the glacier mouth were measured. A number of injections of dye tracers were made to measure the curve of concentration versus time. Finally, a test was made to compare with last year's results, in which the inflow was marked with dye at three different points on the glacier. From the long-term measurements, the daily fluctuations of the average velocity of flow in the intraglacial run-off system and the dispersion coefficient were determined. The results confirm the experiments of last year, showing that the melt water reaches the glacier bed taking the shortest possible route without passing through cavities within the glacier, flowing mostly in an open
channel.
\end{abstract}

RÉsumé. Sur les circulations d'eau du reseau interne de drainage de l'Hintereisferner, Alpes de l'Ötztal, Autriche. Commencées en 1971 et poursuivies en été 1972, les études dont il est rendu compte avaient pour but de rassembler des informations sur le système intraglaciaire d'écoulement de l'eau dans la zone d'ablation de l'Hintereisferner. Au cours d'une longue expérience de $30 \mathrm{~h}$, les fluctuations journalières du débit pénétrant dans un moulin et du débit de l'émission à la sortie du glacier ont été mesurées. Un certain nombre d'injections de colorants ont été faites pour dresser la courbe des concentrations en fonction du temps. Finalement, on a fait un essai pour comparer avec les résultats de l'année précédente pendant laquelle l'eau pénétrant dans le glacier avait été colorée en trois points différents du glacier. A partir de l'expérience de longue durée, on a déterminé les fluctuations journalières de la vitesse moyenne de l'écoulement dans le système de drainage intraglaciaire et le coefficient de dispersion. Les résultats confirment ceux de l'année précédente et montrent que l'eau de fusion gagne le lit du glacier en prenant le chemin le plus court possible sans passer par des cavités à travers le glacier, coulant surtout en chenal ouvert.

Zusammenfassung. Über die Wasserwege des inneren Abflusssystems des Hintereisferners, Ötztaler Alpen, Österreich. Im Jahr 197 I begonnene Untersuchungen wurden im Sommer 1972 fortgesetzt, um nähere Aufschlüsse über das intraglaziale Gerinnesystem im Ablationsgebiet des Hintereisferners zu erhalten. Dabei wurden in einem 30 Stunden währenden Dauerversuch die tageszeitlichen Schwankungen des Zuflusses zu einer Gletschermühle und des Abflusses am Gletschertor gemessen sowie eine Anzahl von Farbstoffimpfungen zur Messung der Konzentrations-Zeit-Kurven durchgeführt. Anschliessend lief ein Vergleichsversuch zu den Messungen im Vorjahr, bei dem an drei verschiedenen Stellen des Gletschers der Zufluss mit Farbe markiert wurde. Aus den Messungen des Dauerversuchs wurden der tageszeitliche Verlauf der durchschnittlichen Fliessgeschwindigkeit und des Dispersionskoeffizienten im intraglazialen Gerinnesystem ermittelt. Die Ergebnisse bestätigen die Versuche des Vorjahrs und zeigen, dass das Schmelzwasser auf kurzem Weg an die Gletschersohle gelangt, keine grösseren Hohlräume innerhalb des Gletschers durchfliesst und seinen Weg weitgehend in einem Freispiegelgerinne zurücklegt.

\section{Introduction}

Only a few studies have hitherto been made on the drainage system of the melt water from a temperate glacier. First indications on the transit time of melt water from the ablation area of the Hintereisferner (Ötztal Alps) were given by Lang (1966). Further Stenborg (1969, 1970) has investigated the internal drainage system of two glaciers in north Sweden (Mikkaglaciären and Storglaciären) by salt injections. The average optimal flow velocity calculated using an air line between the location of injection and the site of measurement were found to be $0.5-0.7 \mathrm{~m} / \mathrm{s}$.

From the diurnal variations of the tritium content of water samples from the streams of the Kesselwandferner and Hintereisferner (Ötztal Alps) it was concluded that the melt water runs off from the ablation area without great delay (Behrens and others, 1971). Due to the 
great contribution of melt water from old glacier ice, minimum concentrations of tritium were measured in samples at the snout of the glacier shortly after the maximum of the diurnal ablation rate. This result demonstrates the rapid run-off of melt water from the ablation area without significant retention.

Röthlisberger (1972) treated the internal drainage system of the glacier from the viewpoint of hydraulics. He pointed out, that melt water can flow in ice channels within the glacier. Melt water is thus not necessarily forced to flow in open channels at the bedrock for long distance.

Krimmel and others (1973) recently investigated the water flow from the South Cascade Glacier, Washington. During the ablation season dyes and salt tracers were used at eight locations distributed over the ablation and accumulation area. The results indicate that the water flow through the ablation area of the South Cascade glacier is mainly in large open conduits.

In the ablation region of Hintereisferner, dye tracer tests were made in moulins and crevasses in summer and autumn of $197 \mathrm{I}$ in order to get information on the run-off of melt water inside the glacier. These tests showed that the marked melt water appears in the Hintereisbach at the glacier snout after a comparatively short time (Ambach and others, 1972). In the summer of 1972 , the studies of 1971 were continued by further tracer tests. It was the purpose of these tests to determine the daily fluctuations of the average velocity of flow. Furthermore, the dispersion coefficient should give information on the water channels within the glacier.

\section{Measuring PRogramme}

\section{I. Long-term test}

Within $30 \mathrm{~h}$, which is more than a diurnial variation, I4 instantaneous (point-type) injections of dye tracer were made every two hours at the inflow of the melt water into the so-called "medium moulin" (Fig. I). The dye concentration was measured in water samples

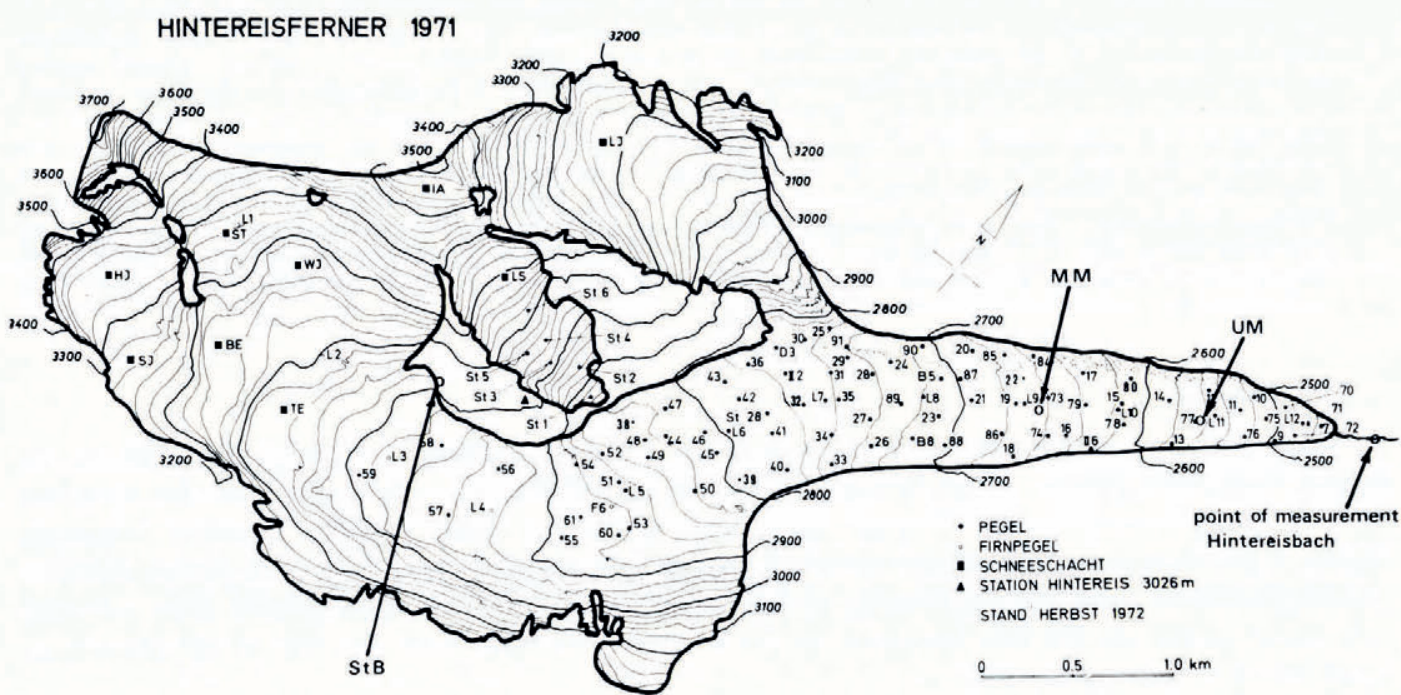

Fig. I. Map of the Hintereisferner with points of injection and the point of measurement: Hintereisbach. For further details on injection points see Table I. We thank the late Professor Dr H. Hoinkes, Head of the Institut für Meteorologie und Geophysik of Universität Innsbruck for permission to use the stake map. 
of the discharge (Hintereisbach) below the glacier snout. From the time intervals between the appearance of the respective tracer clouds, the average velocities of flow and the dispersion coefficients were determined. At the same time, the inflow at the point of injection ("medium moulin") and the discharge at the point of measurement (Hintereisbach) were measured by the dye dilution method (cf. e.g., Behrens and others, r97 I).

\subsection{Comparative experiment}

Instantaneous injections of dye at three different points of the Hintereisferner followed the long-term test; at the "Untere Mühle" (lower moulin), "Mittlere Mühle" (medium moulin), and the "Stationsbach" (station stream) (Fig. I). From the change in concentration with time measured in the glacier discharge near the snout, the average velocity of flow and the dispersion coefficient were determined. While the samples were being taken, the discharge of Hintereisbach near the glacier snout was also measured (in the same way as in the longterm test of section 2.I).

\subsection{Choice of tracer and detection}

Tracer in the samples collected was determined in the laboratory by a selective spectrofluorometric method of measurement with high sensitivity (Behrens, 1973). The choice of tracer at the individual points of injection was such that there was no mutual disturbance possible during the spectrofluorometric determination.

The inflow into moulins was measured with amounts of sulfo-rhodamine $\mathrm{G}$ so small that its concentration in the glacier stream at the snout was usually below the threshold of detection, owing to its dilution. The dyes uranine and rhodamine WT injected into the moulins can be adequately separated by their different spectral regions of fluorescence. The discharge measurements in the Hintereisbach near the glacier snout were made separately with larger amounts of sulfo-rhodamine $\mathrm{G}$, without affecting the detection of dye injected into the moulins, since the samples used for this purpose were taken above the region of discharge measurements.

TABle I. INFLow AND OUTflow DURING DYE TRACER TESTS ON HiNTEREISFERNER

\begin{tabular}{|c|c|c|c|c|c|}
\hline Date & $\begin{array}{c}\text { Time } \\
\mathrm{h}\end{array}$ & $\begin{array}{l}\text { Point of } \\
\text { injection }\end{array}$ & $\begin{array}{l}\text { Amount } \\
\text { of dye } \\
\mathrm{g}\end{array}$ & $\begin{array}{c}\text { Inflow at the } \\
\text { point of injection } q \\
1 / \mathrm{s}\end{array}$ & $\begin{array}{c}\text { Discharge at the } \\
\text { point of measurement } Q \\
\mathrm{~m}^{3} / \mathrm{s}\end{array}$ \\
\hline 24 July 1972 & $\begin{array}{l}10.00 \\
12.00 \\
14.00 \\
16.00 \\
18.00 \\
20.00 \\
23.00\end{array}$ & $\begin{array}{l}\text { MM } \\
\text { MM } \\
\text { MM } \\
\text { MM } \\
\text { MM } \\
\text { MM } \\
\text { MM }\end{array}$ & $\begin{array}{l}50 \mathrm{U} \\
50 \mathrm{U} \\
50 \mathrm{U} \\
50 \mathrm{U} \\
50 \mathrm{U} \\
50 \mathrm{U} \\
50 \mathrm{U}\end{array}$ & $\begin{array}{r}8.5 \\
28.5 \\
43.0 \\
55.0 \\
34.0 \\
21.0 \\
\text { I2.0 }\end{array}$ & $\begin{array}{l}6.1 \\
6.2 \\
6.7 \\
7.1 \\
6.6 \\
6.6 \\
6.6\end{array}$ \\
\hline 25 July 1972 & $\begin{array}{l}02.01 \\
05.00 \\
08.00 \\
10.00 \\
12.00 \\
14.00 \\
16.00\end{array}$ & $\begin{array}{l}\text { MM } \\
\text { MM } \\
\text { MM } \\
\text { MM } \\
\text { MM } \\
\text { MM } \\
\text { MM }\end{array}$ & $\begin{array}{l}50 \mathrm{U} \\
50 \mathrm{U} \\
50 \mathrm{U} \\
50 \mathrm{U} \\
50 \mathrm{U} \\
50 \mathrm{U} \\
50 \mathrm{U}\end{array}$ & $\begin{array}{r}6.5 \\
5.0 \\
6.5 \\
16.5 \\
34.0 \\
53.5 \\
40.5\end{array}$ & $\begin{array}{l}5.9 \\
5.4 \\
6.0 \\
7.9 \\
8.3 \\
8.4 \\
7.8\end{array}$ \\
\hline 27 July 1972 & $\begin{array}{l}09.15 \\
10.00 \\
10.00\end{array}$ & $\begin{array}{l}\text { StB } \\
\text { MM } \\
\text { UM }\end{array}$ & $\begin{array}{l}400 \mathrm{U} \\
400 \mathrm{RWT} \\
\text { I0o U }\end{array}$ & $\begin{array}{r}4.0 \\
13.5 \\
35.0\end{array}$ & $\begin{array}{l}5.5 \\
6.2 \\
6.0\end{array}$ \\
\hline
\end{tabular}

$\mathrm{UM}=$ Untere Mühle (lower moulin), $800 \mathrm{~m}$ from point of measurement.

$\mathrm{MM}=$ Mittlere Mühle (medium moulin), $\mathrm{I} 700 \mathrm{~m}$ from point of measurement.

$\begin{aligned} \mathrm{StB} & =\text { Stationsbach (station stream), } 5200 \mathrm{~m} \text { from point of measurement (cf. Fig. I). } \\ \mathrm{U} & =\text { Uranine. }\end{aligned}$

RWT $=$ Rhodamin WT . 


\section{Evaluation}

\subsection{Inflow and discharge measurements}

The results of these measurements are shown in Table I.

\subsection{Concentration-time curves}

For taking samples at the different points of measurement, the method of continuous sampling at constant withdrawal rate was usually applied (Behrens and others, 1971). Exceptionally after the injections of 24 July 1972, 23.00 h and 25 July 1972, 2.0 I h, individual samples (instantaneous samples) were taken for technical reasons. The results of concentration measurements are shown in Figure 2 for the long-term test (section 2.I) and in Figure 3 for the comparative experiment (section 2.2).

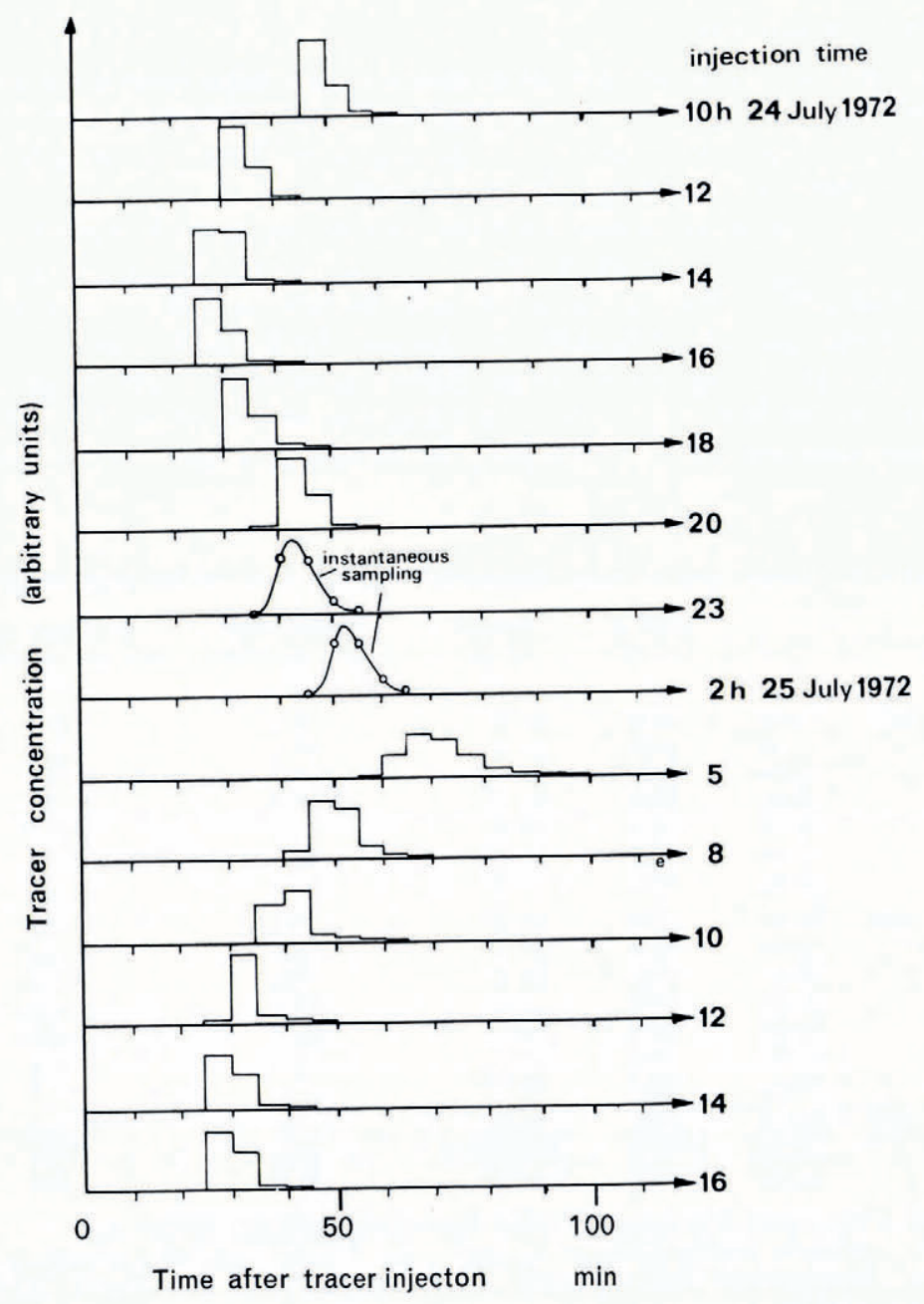

Fig. 2. Concentration-time curves of the long-term test. 


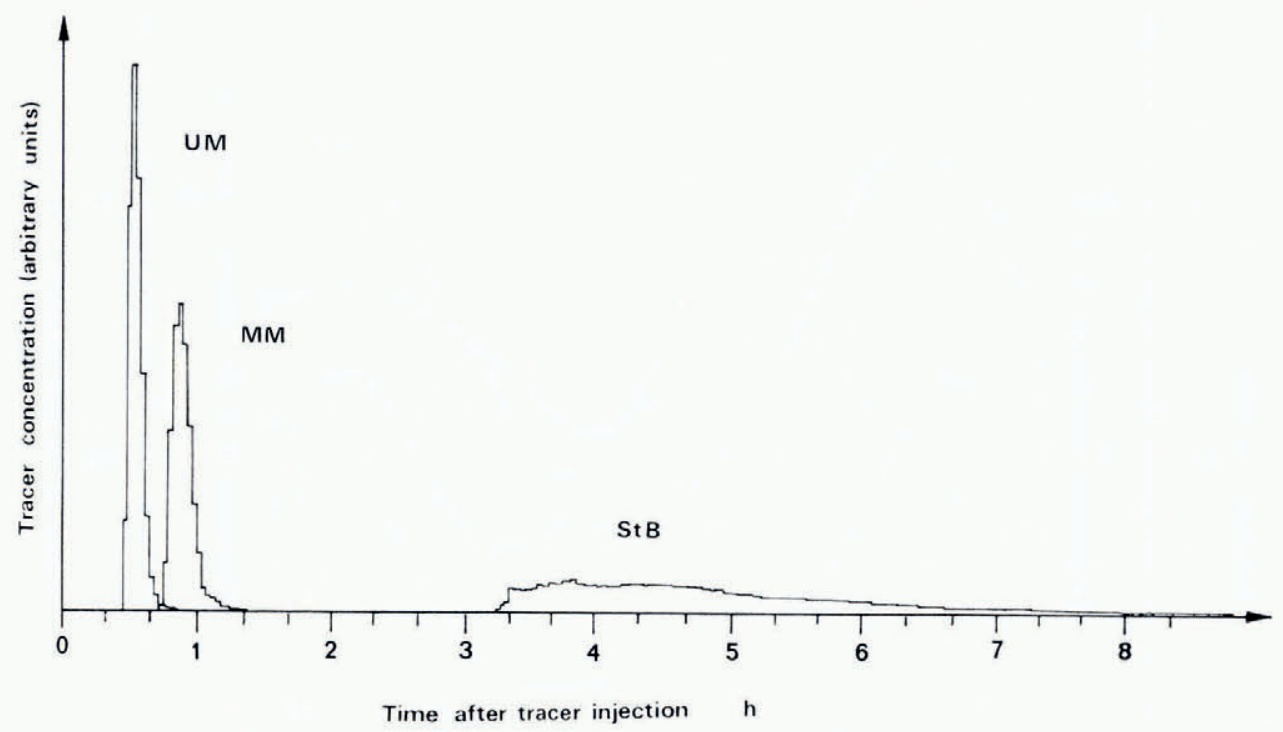

Fig. 3. Concentration-time curves of the comparative test.

\subsection{Dispersion coefficient and velocity of flow}

The curve of concentration versus time after an instantaneous injection may be described approximately by the linear dispersion equation

$$
\frac{\partial c}{\partial t}=D \frac{\partial^{2} c}{\partial x^{2}}-u \frac{\partial c}{\partial x}
$$

(e.g. Taylor, 1954; Fischer, I968), where $D$ is the dispersion coefficient, $u$ is the average velocity of flow, $x$ is the distance of the point of measurement from the point of injection, $t$ is the time of flow, and $c$ is the tracer concentration (in dye units per unit volume). For a point of measurement at which the samples are taken, having a distance of $x_{\mathrm{m}}$ from the point of injection, the following concentration-time relation is obtained as a solution to Equation (I):

$$
c\left(x_{\mathrm{m}}, t\right)=\frac{A}{(4 \pi D t)^{\frac{1}{2}}} \exp \frac{-\left(x_{\mathrm{m}}-u t\right)^{2}}{4 D t} .
$$

In Equation (2), $A$ is a constant proportional to the amount of injected tracer per unit area. It is possible to describe the most important part of the dependence of concentration on time with sufficient accuracy by using Equation (2), although it has been shown that there exist systematic deviations at the end of the curve (Ambach and Jochum, 1973). Owing to the diurnial variations of the melt-water discharge, a diurnial variation of the average velocity of flow $u$ and of the dispersion coefficient $D$ of Equation (2) are to be expected.

The concentration-time curves shown in Figures 2 and 3 were evaluated by approximating to the measured curves (stepped diagram) by means of Equation (2).

The values of average velocity of flow $u$ and of the dispersion coefficient $D$ determined for the long-term test are given in Figure 4 together with the inflow $q$ to the moulin and discharge $Q$ of the glacier stream near the glacier snout. Figure 5 shows the dispersion coefficient $D$ as a function of the average velocity of flow $u$ for the series of the long-term test. The points scatter without any systematic deviation around a plotted trend line. 


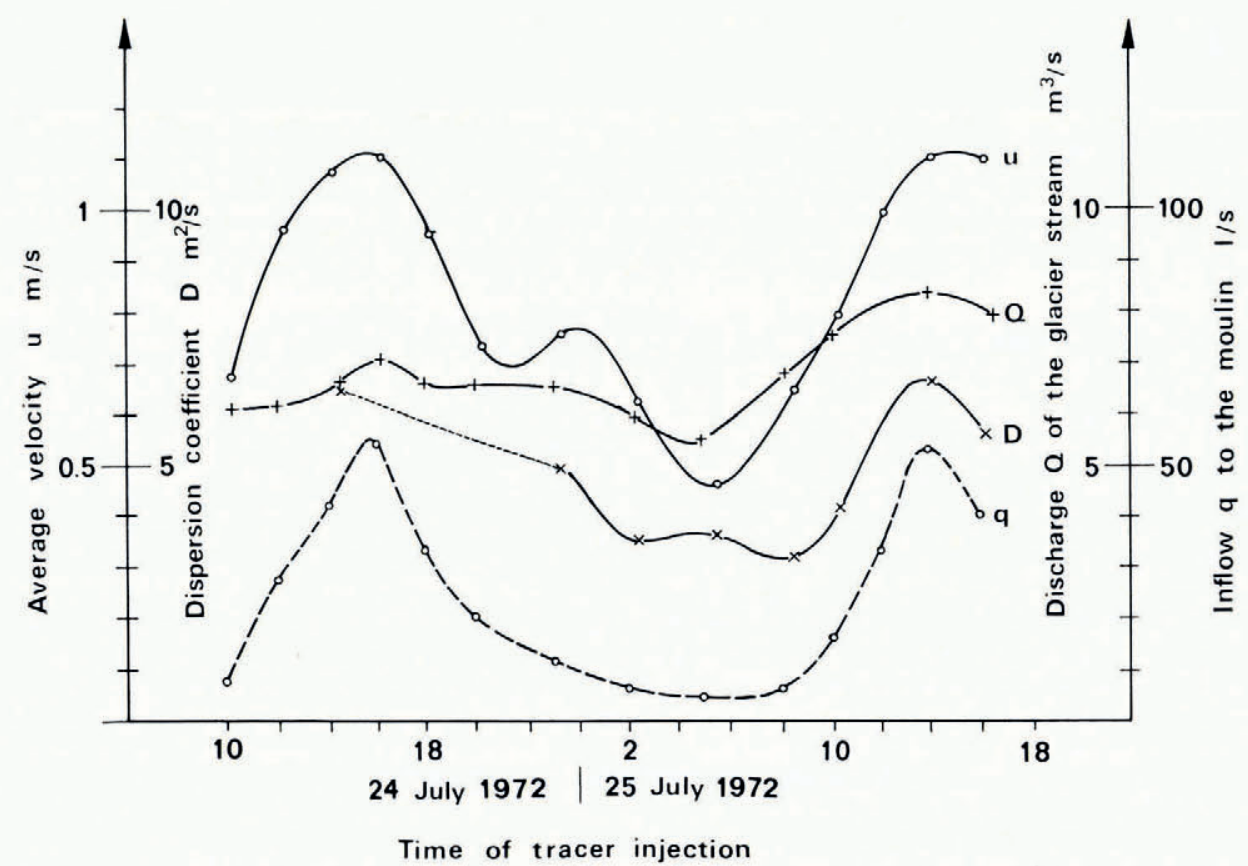

Fig. 4. Progress lines of inflow and outflow ( $q$ and $Q$, respectively), dispersion coefficient $D$, and average velocity of flow $u$.

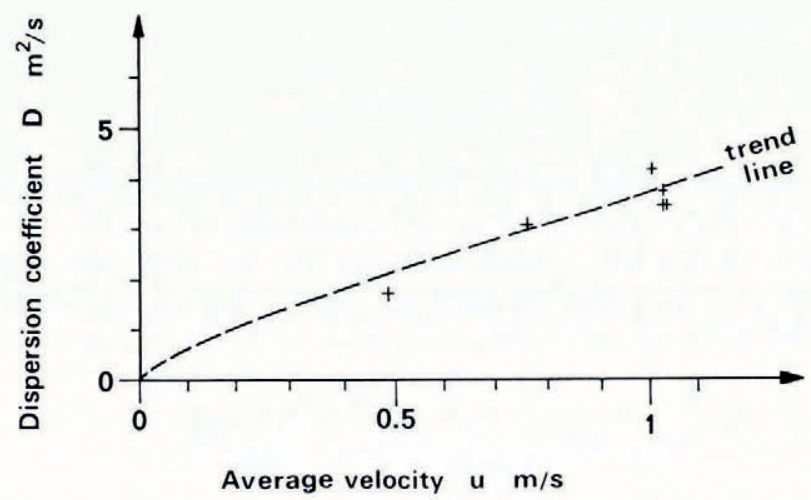

Fig. 5. Relation between the dispersion coefficient $D$ and the average velocity of flow $u$.

According to Fischer (1968), there exists a relation between the dispersion coefficient $D$ and the hydraulic properties of a channel system of the form

$$
D=a R v^{+} \text {, }
$$

where $R$ is the hydraulic radius of the channel, $v^{+}$is the shear velocity, and $a$ is a characteristic parameter of the channel (the so-called non-dimensional dispersion coefficient). The shear velocity $v^{+}$is proportional to the mean velocity $v$ (cf. Press and Schröder, I966). Because the discharge along the distance between the injection and measuring points is changing very slowly in relation to the travelling time of the tracer, the mean velocity $v$ at the measuring point can be assumed to be approximately proportional to the average flow velocity $u$ between the points of injection and of measurement. 
Assuming, that the hydraulic radius has no essential variation during the day, and that the quantity $a$ is a constant average value for a certain channel distance, Equation (3) may be simplified to

$$
D=\text { const. } u \text {. }
$$

\section{Results}

The studies of summer 1972 on the water channels in the internal drainage system of Hintereisferner have shown the following results:

4.I. The results gathered in summer I97 I (cf. Ambach and others, 1972) were largely confirmed by the new studies. In particular the measured times of flow and the concentration-time curves of the two periods are in good agreement. Hence it may be concluded that no detectable change in the structure of the intraglacial system of channels occurred.

4.2. Stenborg (1969, 1970) from his measurements on two glaciers in Sweden gives average values for optimal velocity of flow between 0.5 and $0.7 \mathrm{~m} / \mathrm{s}$ for intraglacial melt water. The average velocities of flow measured on the Hintereisferner from dye tracer tests of 1971 and 1972 are between 0.47 and $1.11 \mathrm{~m} / \mathrm{s}$, thus being in good agreement with the values given by Stenborg. Hence it may be assumed that the values obtained for the average velocity of flow also hold outside the local region tested, being of great help for studies on other glaciers.

4.3. The rates of recovery of injected dye are above $90 \%$ (the lowest value measured was $89 \%$ ). These high values show that the chosen tracers are well suited for examining intraglacial channel systems.

4.4. During the long-term test of $30 \mathrm{~h}$, the samples were taken with a duration of $5 \mathrm{~min}$ per sample, since originally only the time of flow was to be measured. The passage of a tracer cloud at the point of measurement (until about $90 \%$ of the dye had appeared) was found to take no more than 15 to 20 min. Hence the time of taking samples is comparatively long as compared to the time of passage of a tracer cloud. In individual cases, the amount of data was therefore too small for a dispersion analysis. For exact dispersion examinations, the tracer passage curve could therefore be made more accurate by taking samples in shorter time intervals.

4.5. Figure 5 shows an approximately linear relation between the dispersion coefficient $D$ and the average velocity of flow $u$ in agreement with Equation (4). The assumptions for the validity of Equation (4) have to be examined. Apart from this aspect, the linear experimental relation of Figure 5 can be explained from a hydraulic viewpoint by Equation (4).

4.6. The progress line of the inflow $q$ to the "Mittlere Mühle" (medium moulin) represents a locally confined discharge event, being insufficiently representative for the entire melting process of the Hintereisferner. It is therefore not possible to draw any conclusion from the measured inflow progress line $q$ as compared with the measured outflow line $Q$ of Hintereisbach as to the diurnial storage process within the glacier.

4.7. The concentration-time curves (Figs 2 and 3) measured after the dye tracer has passed through the Hintereisferner, compared with the concentration-time curves measured earlier on the Hintereisbach without passage through the glacier (Behrens and others, unpublished) show a similar character as far as shape and dispersion coefficients are concerned. This gives a clue that the dye tracer inside the glacier flows largely in an open channel at the glacier bed getting there along the shortest route after being injected at the glacier surface. This agrees with the results of earlier examinations (Ambach and others, 1972) according to which there do not exist any large water-filled cavities along the channels inside the glacier. 


\section{ACKNOWLEDGements}

The authors wish to thank the Österreichische Akademie der Wissenschaften, Wien, for financial support and the Bundesministerium für Inneres for transportation of material. Sincere gratitude is also expressed to the assistants in the field work.

MS. received I4 January 1975 and in revised form 7 April 1975

\section{REFERENCES}

Ambach, W., and Jochum, O. 1973. Zur Dispersion im offenen Gerinne: Einfluss von Randzonen bei Gletscherbächen. Zeitschrift für Gletscherkunde und Glazialgeologie, Bd. 9, Ht. 1-2, p. 181-88.

Ambach, W., and others. 1972. Markierungsversuche im inneren Abfluss-System des Hintereisferners (Ötztaler Alpen), von W. Ambach, H. Behrens, H. Bergmann und H. Moser. Zeitschrift für Gletscherkunde und Glazialgeologie, Bd. 8, Ht. I-2, p. 1 $37-45$.

Behrens, H. 1973. Eine verbesserte Nachweismethode für Fluoreszenzindikatoren und ihre Anwendung zur Feststellung von Fliesswegen im Grundwasser. Zeitschrift der Deutschen Geologischen Gesellschaft, Bd. 124, Teil 2, p. 535-44.

Behrens, H., and others. 1971. Study of the discharge of alpine glaciers by means of environmental isotopes and dye tracers, by H. Behrens, H. Bergmann, H. Moser, W. Rauert, W. Stichler and W. Ambach, H. Eisner, K. Pessl. Zeitschrift für Gletscherkunde und Glazialgeologie, Bd. 7, Ht. I-2, p. 79-102.

Behrens, H., and others. Unpublished. Abflussmessungen in einem vergletscherten Einzugsgebiet mit Hilfe der Indikatorverdünnungsmethode, von H. Behrens, H. Moser, W. Rauert und W. Ambach.

Fischer, H. B. 1968. Methods for predicting dispersion coefficients in natural streams, with applications to lower reaches of the Green and Duwamish Rivers, Washington. U.S. Geological Survey. Professional Paper 582-A.

Hoinkes, H. C. 1970. Methoden und Möglichkeiten von Massenhaushaltsstudien auf Gletschern. Ergebnisse der Messreihe Hintereisferner (Ötztaler Alpen) 1953-1968. Zeitschrift für Gletscherkunde und Glazialgeologie, Bd. 6, Ht. I-2, p. 37-9o.

Krimmel, R. M., and others. 1973. Water flow through a temperate glacier, [by] R. M. Krimmel, W. V. Tangborn and M. F. Meier. (In [International Hydrological Decade.] The role of snow and ice in hydrology. Proceedings of the Banff symposia, September 1972. Paris, UNESCO; Geneva, WMO; Budapest, IAHS, p. 40I-16.)

Lang, H. I966. Hydrometeorologische Ergebnisse aus Abflussmessungen im Bereich des Hintereisferners (Ötztaler Alpen) in den Jahren 1957 bis r959. Archiv für Meteorologie, Geophysik und Bioklimatologie, Ser. B, Bd. I 4 , Ht. 3-4, p. 280-302.

Press, H., and Schröder, R. 1966. Hydromechanik im Wasserbau. Berlin, Ernst und Sohn.

Röthlisberger, H. 1972. Water pressure in intra- and subglacial channels. Journal of Glaciology, Vol. i I, No. 62, p. $177-203$.

Stenborg, T. 1969. Studies of the internal drainage of glaciers. Geografiska Annaler, Vol. 51 A, Nos. I-2, p. I3-41.

Stenborg, T. 1970. Delay of run-off from a glacier basin. Geografiska Annaler, Vol. 52A, No. I, p. I-30.

Taylor, G. I. 1954. The dispersion of matter in turbulent flow through a pipe. Proceedings of the Royal Society of London, Ser. A, Vol. 223, No. 1155 , p. 446-68. 